\title{
DETECTION OF SOME PARASITES IN LIVERS AND SPLEENS OF SLAUGHTERED CATTLE
}

\author{
WAFAA G. MAHMOUD ${ }^{1}$; NAGWA T. ELSHARAWY ${ }^{2}$; ALSHIMAA A. HASSANIEN ${ }^{3}$ \\ AND ABEER A. KHEDR ${ }^{1}$ \\ ${ }^{1}$ Parasitology Department, Faculty of Veterinary Medicine, New Valley University, Egypt \\ ${ }^{2}$ University of Jeddah, College of Science, Department of Biology, Saudi Arabia \\ and Department of Food Hygiene, Faculty of Veterinary Medicine, New Valley University, Egypt. \\ ${ }^{3}$ Department of Zoonoses, Faculty of Veterinary Medicine, Sohag University, Egypt.
}

Received: 11 December 2019; Accepted: 29 December 2019

\begin{abstract}
Parasitic infections retarded growth rate, decrease milk and meat production, abortion, and mortality which leading to huge economic losses in addition to its zoonotic impacts. Slaughterhouses used to monitor the infectious disease among food animals and play an important role in eliminating various diseases and prevent the transmission of infectious and zoonotic diseases to humans. The study aimed to identify the protozoan and uncommon nematodes larvae that affect cattle in New-Valley Governorate, Egypt. All slaughtered cattle's slaughtered at El-Kharga abattoir were inspected for the presence of Theileria spp., Toxoplasma gondii (T. gondii), and Ascarid larvae during the period from July 2017 to the end of November 2018. Eighty livers and twenty spleens were examined by tissue impression smear stained with Giemsa stain to detect the prevalence of the parasites that embedded in the liver and spleen tissue, the prevalence of Theileria spp. was $62.5 \%$ in liver samples and $60 \%$ in spleen samples, while prevalence of T. gondii was $(10 \%)$ in the spleen. However, the percentage of T.gondii in the liver was $1.25 \%$. Five percent of examined cattle's have been infected by Ascarid larva, which was found mainly in spleen. More education programs to farmers, veterinarians and improved public awareness are recommended. Broad spectrum anthelmintic must be applied to the animals' pasture. Future molecular biological studies are recommended to find out if the Theileria spp., Toxoplasma spp. and Ascarid larvae encountered in New-Valley cattle are pathogenic human genotypes will represent a serious health problem especially for populations who comes in contact with cattle.
\end{abstract}

Keywords: Theileria spp., T. gondii, Ascarid larvae, edible offals, zoonoses, slaughterhouse.

\section{INTRODUCTION}

Cattle are one of great economic importance, which is considered the main source of meat, milk and hides in Egypt. Such meat is the most common animal protein for human consumption, so it should be free from diseases particularly parasites (Radwan, 2008). The raring of cattle's is one of the most beneficial industries worldwide. Thus, the total number of cattle in 2013 represented 54 million heads all over the world while in Egypt had about 148 thousand local heads and 4 million 579 thousand foreign heads (ADOD, 2014).

Parasitism is the main cause of cattle production reduction globally. Parasites have been noted the

Corresponding author: Dr. NAGWA T. ELSHARAWY

E-mail address: dr.nagwa2004@yahoo.com

Present address: University of Jeddah, College of Science, Department of Biology, Saudi Arabia and Department of Food Hygiene, Faculty of Veterinary Medicine, New Valley University, Egypt. major constraints to ruminants' productivity in terms of pathology and economic importance. Several worms are found in the animal, such as trematodes, cestodes, nematodes, and protozoa (Pam et al., 2013).

Nematodes (roundworms) are worms that infect the ruminants. Large numbers of roundworms can cause a nutritional disturbance. Developing and migrating larvae and feeding adult worms can cause sufficient damage to the animal edible organs. They also interfere with digestion and cause blood losses. Infections of protozoa are common and seen during microscopic examinations. Infected animals are considered carriers and possible sources of infection for susceptible animals (Kahn et al., 2010).

The causative agent of East Coast Fever (ECF) is Theileria Parva which one of the tick-borne apicomplexan parasites of wildlife and most domestic animal species, predominantly ruminants, which cause acute lymphoproliferative growth which results in high mortality levels of cattle. Clinically evident as lymph node enlargement, and infiltration of other 
tissues; the lungs, gastrointestinal tract, by parasitized cells (Morrison, 2015).

T. gondii is an obligate intracellular tissue cystforming protozoan; the disease is affecting a wide range of different animal species in Egypt, causing serious economic losses all over the world (Abd ElRazik et al., 2014). In addition, its zoonotic impact especially in pregnant women and immunocompromised persons causing a serious illness (leonard et al., 2019).

Animal grazing habits, pasture management, nutritional deficiency, the immunological status of intermediate vector and host, climates, the number of infective larvae and eggs in the environment were the main routes in the transmission of the parasites. Mature worms' toxins' destroy Red Blood Cells, due to which unthrifty anemic conditions are generated. While immature worms migrating through the body tissues of animals open the way for bacteria and fungi to enter, which causes serious diseases (Raza et al., 2013 ).

The losses caused by parasitic infections are in the form of lowered general health condition, retarded growth rate, diminishing the working efficiency, decrease milk and meat production, abortion, and mortality. On the other hand, the cattle may be infected by parasites for a longer period of time in milk or breeding production which resulting in enormous economic losses (Akand a et al., 2014).

The infections are either clinical or subclinical, the latter being the most common and of great economic importance. Although clinical parasitism has received considerable attention as a result of obvious severity (Abouzeid et al., 2010).

Slaughterhouses could be used to monitor the infectious disease status among food animals and play an important role in eliminating various diseases that are not fit for human consumption (Elmonir et al., 2015).

Meat inspection also provides vital data and valuable information on the incidences and prevalence of animal diseases and conditions within any country to prevent the transmission of infectious and zoonotic diseases to humans. Well documentation and collection of this information will make changes in animal husbandry practices and disease control (Phiri, 2006).

The aim of the present work is to identify some parasites that affect cattle in New-Valley Governorate which is highly beneficial in planning control measures against these parasites. Hence, a survey of helminths and protozoan parasites is going to be done through; Examination of samples collected from cattle attended El-Kharga abattoir from different localities in New-Valley Governorate, Studying the morphological features by these parasitic stages; Gross appearance and tissue impression smears of digestive system organs to detect different parasitic stages in cattle's.

\section{MATERIALS AND METHODS}

Ethical approval: This study has been approved by the Animal Rights and Ethical Use Committee of New Valley University, Egypt.

The study area: A cross-sectional study was conducted in El-Kharga abattoirs to detect the prevalence of Theileria spp., T. gondii, and Ascarid larvae infection in slaughtered cattle. El-Kharga city is the capital of New Valley Governorate. It is a part of the oasis, which is located to the west of the Nile Valley between $25.26^{\circ} \mathrm{N}$ latitude and $30.32^{\circ} \mathrm{E}$ longitude. El-Kharga abattoir slaughtered about 2540 bovine animals during 2017/2018. About 80 infected liver samples ( 75 cattle $\& 5$ bovine) and 20 spleen samples (15 cattle \& 5 bovine) samples were collected from all cattle and bovine which slaughtered at El-Kharga abattoir during daily inspection for the presence of Theileria spp., T. gondii and Ascarid larvae infection during the period from July 2017 to the end of November 2018.

\section{Samples preparation:}

Liver and spleen samples were collected randomly from slaughtered cattle's during the period of the experiment. Immediately after opening the carcass, liver and spleen samples were obtained with sterile single-use surgical blades and transferred into sterile plastic bags and examined for the purpose of studying liver and spleen parasites. Each sample was collected in a clean plastic cup and taken directly to the laboratory for examination.

\section{Macroscopic examination of liver and spleen: (Griffiths 1978)}

Examination performed by the naked eyes during the routine abattoir post mortem examination. The livers $\&$ spleen were palpated consistency, color, presence or absence of hemorrhage, presence of mucus or other unusual constituents, were noticed through the examination of samples by the naked eye and dissected for any parasites.

\section{Microscopic examination:}

\subsection{Tissue impression smears: (Maslin and} Latimer, 2009)

A total of 100 impression smears from internal organs were made from 20 spleens and 80 livers. These visceral smears were examined after staining with Giemsa stain for the detection of tissue stages of different parasites microscopically under the oil immersion lens. 


\subsection{Preparation of Giemsa stain (Lawrence and Thomas, 1987)}

Stock Giemsa stain was prepared by mixing $3 \mathrm{gm}$ of Giemsa powder with $250 \mathrm{ml}$ Glycerin in a mortar until the powder was dissolved. The mixture was put in a flask and placed in a $60^{\circ} \mathrm{C}$ water bath for 2 hours, and then $250 \mathrm{ml}$ absolute methyl alcohol was added. The stock solution was stored in a tightly stoppered dark bottle for two to four weeks.

\section{RESULTS}

\section{Prevalence of parasitic infection in tissue impression smears:}

The results of the examination of 100-impression smear of internal organs of cattle are presented in table (1) and figure (1); the total prevalence of Theileria spp. was $62.5 \%$ in liver samples and $60 \%$ in spleen samples, while $T$. gondii was detected in spleen and liver with percentage $10 \%$ and $1.25 \%$ respectively. Ascarid larvae was detected in $5 \%$ of examined cattle only in spleen.

\section{Microscopic examination of tissue impression smears:}

The inspection of liver and spleen of cattle were found to be infected with a wide variety of protozoa (Theileria spp., T. gondii) and Ascarid larva as following.

\subsection{Theileria spp.}

The prevalence of Theileria spp. in tissue impression smear tabulated in table (1) was about $62 \%$ from the inspected carcass, as following; 50/80 (65.2\%) and $12 / 20(60 \%)$ in liver and spleen respectively.

2.1.1. Morphology of schizonts: Schizonts were seen in smears made from livers (Figure 2; A, B, C \& D) and spleens (Figure 2; E \& F). Two types of schizonts of Theileria spp., small and large schizonts were observed in spleen and liver smears.

2.1.2. Small schizont: The small schizonts (Figure 2; $\mathrm{A} \& \mathrm{~B}$ ) in the liver and (Figure 2; E \& F) in the spleen. Merozoites in the small schizonts were comma-shaped; the schizonts were not commonly seen inside the host cells. The merozoites in small schizont were varied.

2.1.3. Large schizont: The Large schizonts were located outside the host cell rarely observed inside the host cell. Scattered merozoites were also observed. The sizes of merozoites in these large schizonts were different, some of them being large and some small (Figure 2; C \& D).

\subsection{Toxoplasma gondii:}

The prevalence of $T$. gondii in tissue impression smear tabulated in the table (1) was about $3 \%$ from the inspected carcass, as following; $1 / 80(1.25 \%)$ and $2 / 20(10 \%)$ in liver and spleen respectively. The size of tissue cysts was variable, measured from 50 to 70 $\mu \mathrm{m}$ and contains from 16-30 crescent-shaped tachyzoites. The cyst size inside the tissue is dependent on the host cell, cyst age, and the strain of Toxoplasma gondii. In small cysts detected inside host spleen tissue (Figure 3; A) and liver tissue (Figure 3; B) measuring with average $5 \mu \mathrm{m}$ and containing few tachyzoites with vacuoles of different sizes.

\subsection{Ascarid larva:}

The prevalence of Ascarid larva in tissue impression smear tabulated in the table (1) was about $1 \%$ from the inspected carcass, as following; $0 / 80(0 \%)$ and $1 / 20(5 \%)$ in liver and spleen respectively. The size of third stage larvae ranging from $0.56-1.07 \mathrm{~mm}$ in length and $0.03-0.05 \mathrm{~mm}$ in width (Figure 4; A). It is a cone-like structure with thick granular sheath (Figure 4; B).

Table 1: Prevalence of parasitic infection in tissue impression smear.

\begin{tabular}{|c|c|c|c|c|}
\hline \multirow{3}{*}{ parasitic infection } & \multicolumn{2}{|c|}{ Liver } & \multicolumn{2}{|c|}{ Spleen } \\
\hline & \multicolumn{2}{|c|}{ Examined no. $=80$} & \multicolumn{2}{|c|}{ Examined no. $=20$} \\
\hline & Infected no. & $\%$ & Infected no. & $\%$ \\
\hline Theileria spp. & 50 & 62.5 & 12 & 60 \\
\hline Toxoplasma gondii & 1 & 1.25 & 2 & 10 \\
\hline Ascarid larvae & 0 & 0 & 1 & 5 \\
\hline Total & 51 & 63.8 & 15 & 75 \\
\hline
\end{tabular}




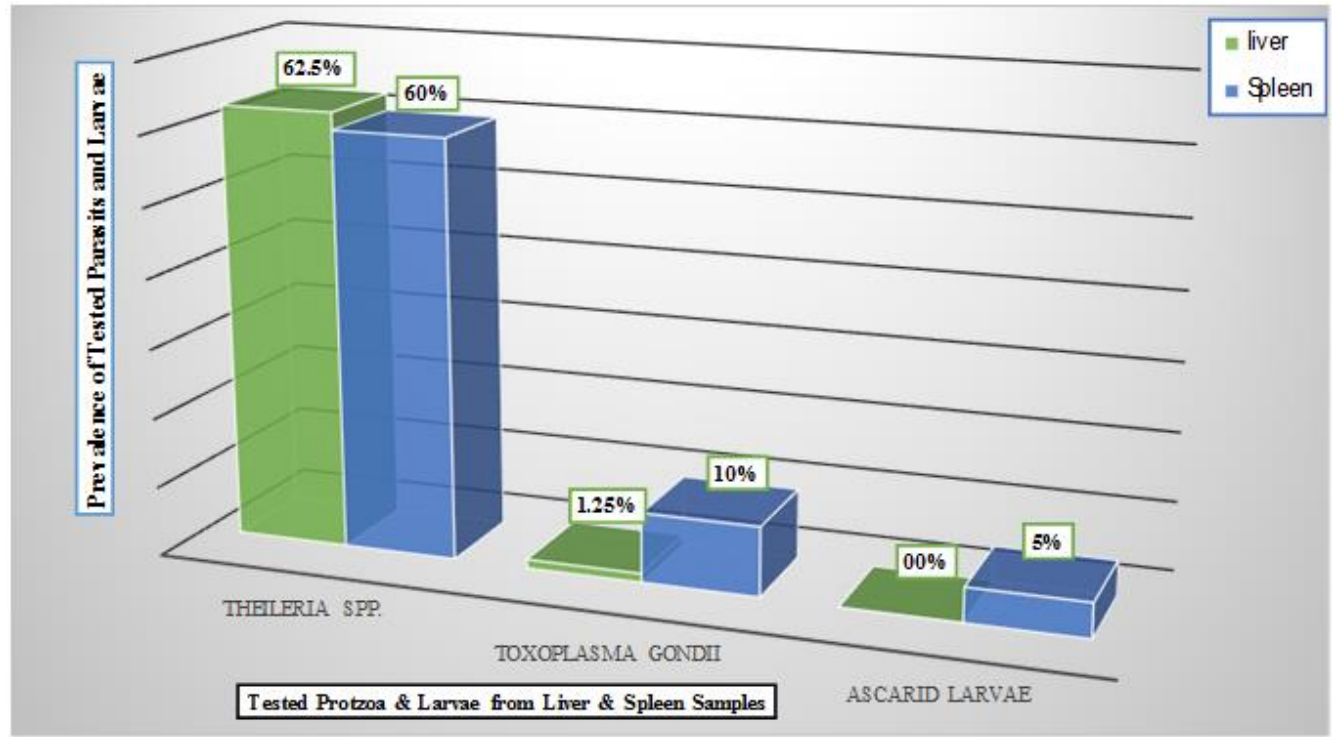

Figure (1): Histogram showing the prevalence of parasitic infection in tissue impression smear

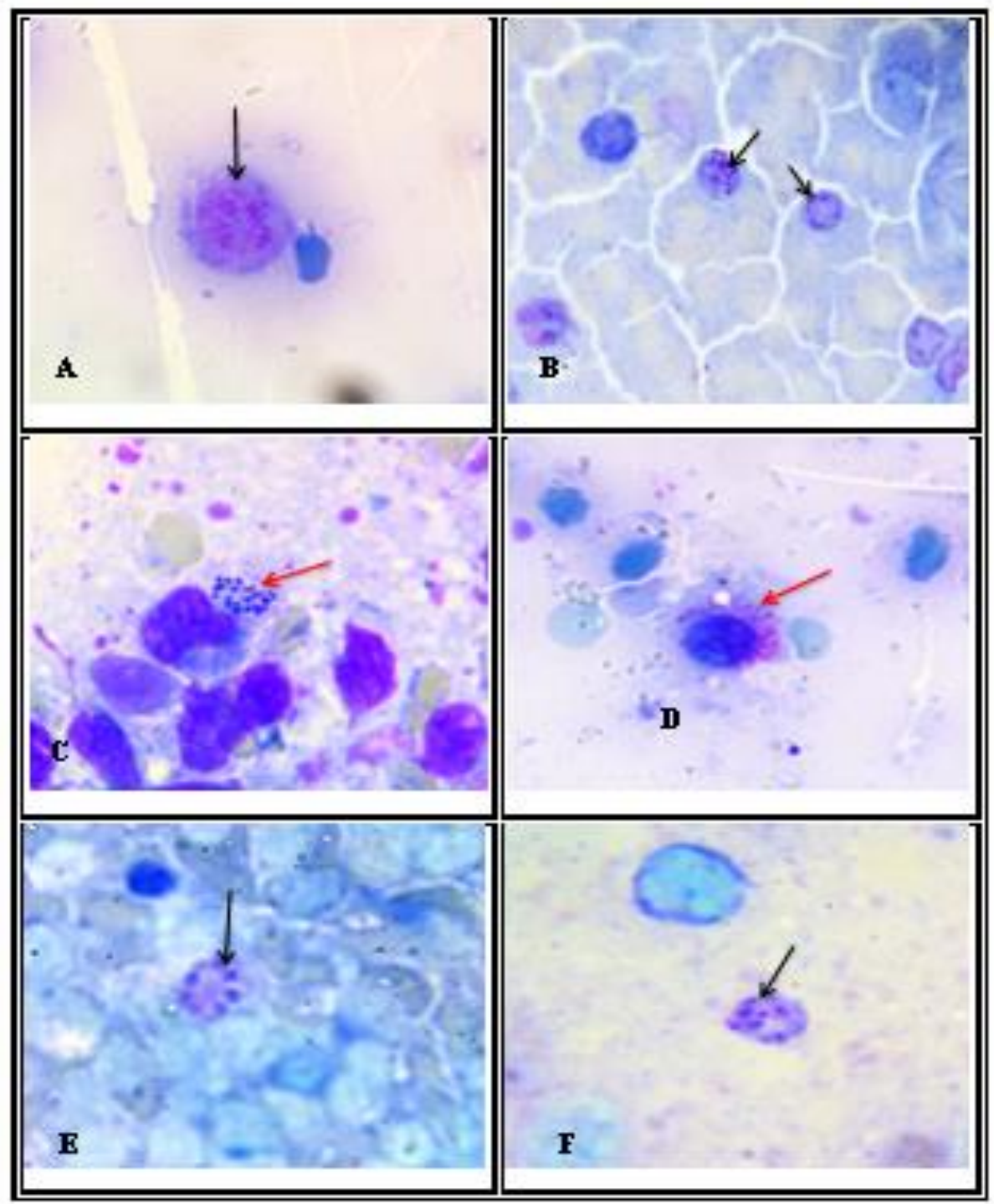

Figure (2): Microscopic view of smear made from Liver (Fig. A, B “intracellular schizont”, C, D “extracellular schizont” and Spleen (Fig. E, F “intracellular schizont” (x100). 


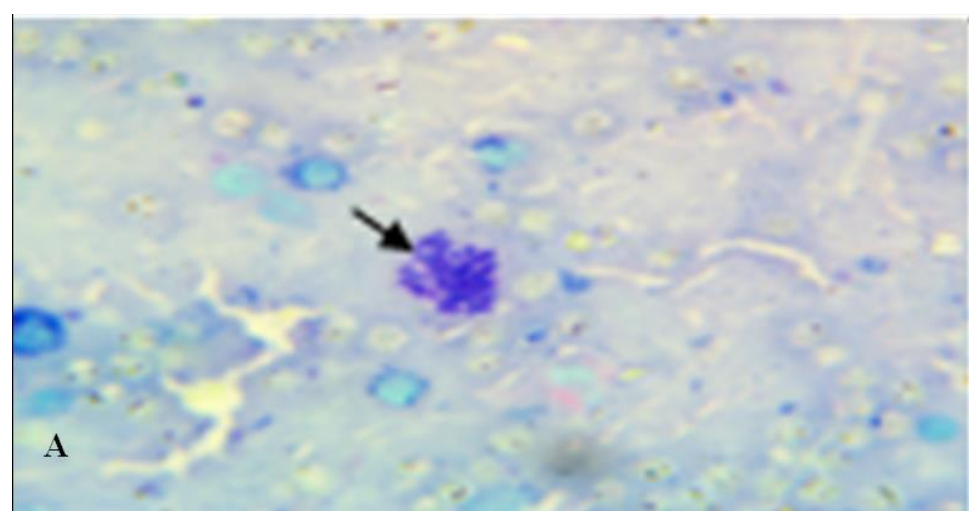

Figure (3): A) Tissue cyst of Toxoplasma gondii in spleen of infected cattle stained by Geimsa stain (X 100)

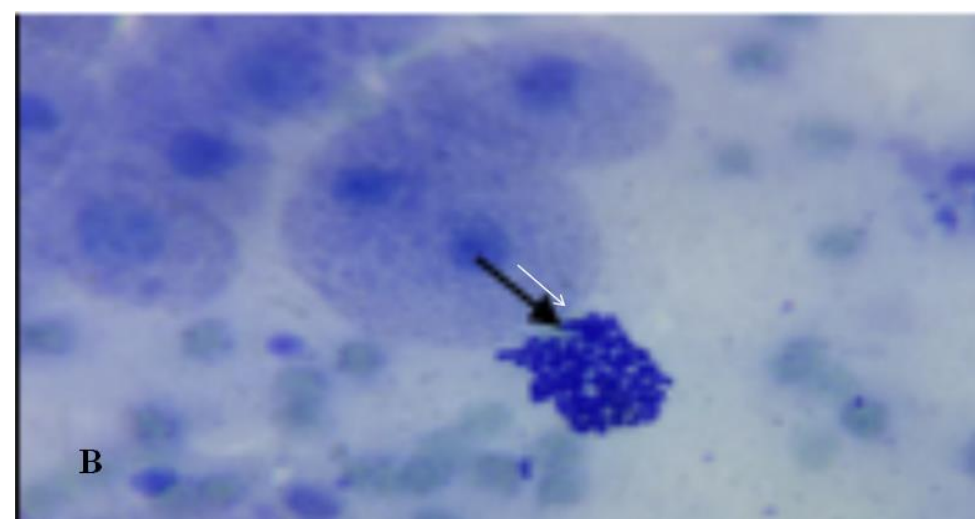

Figure (3): B) Tissue cyst of Toxoplasma gondii in liver of infected cattle stained by Geimsa stain (X100).

Figure (3): Impression smear of Toxoplasma gondii.

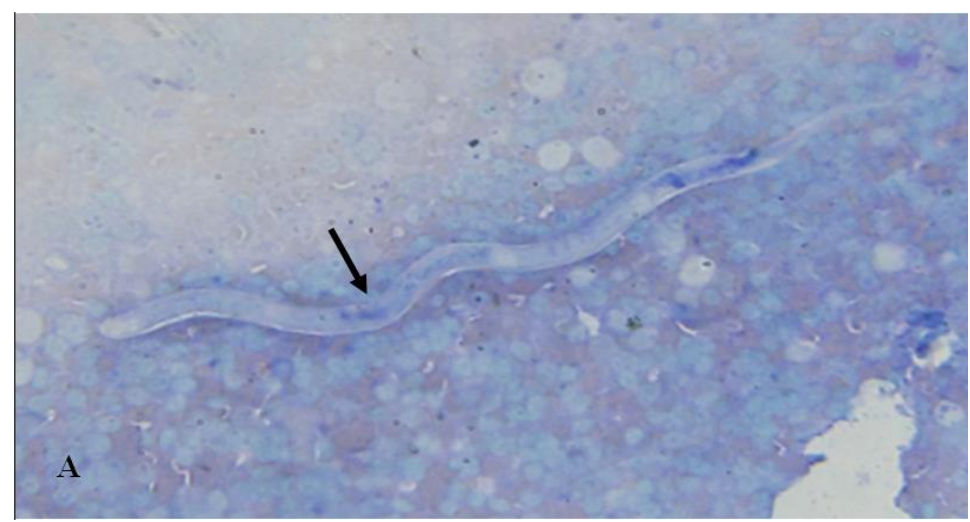

Figure (4): A) Microscopic examination of tissue impression smear showing Ascarid larva in the spleen (x100)

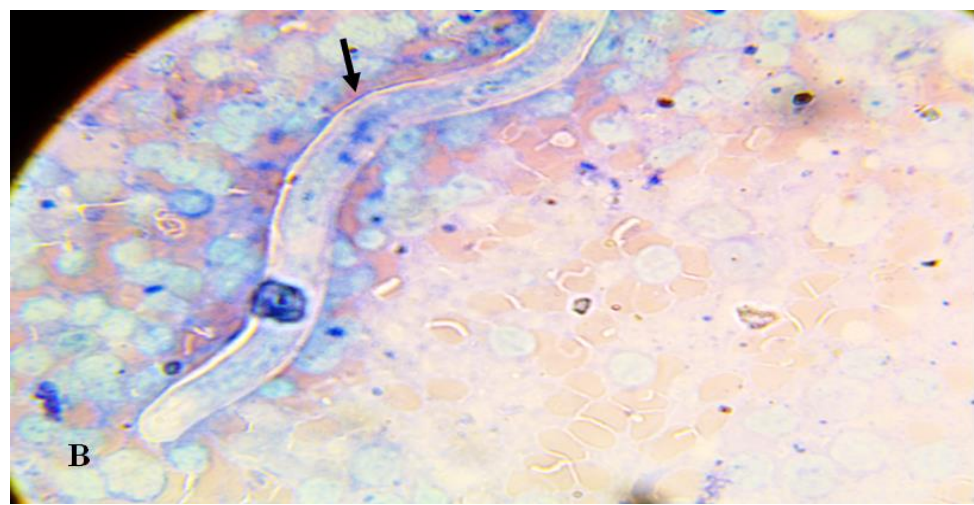

Figure (4): B) Ascarid larvae showing granular cone at the anterior end (x100). Figure (4): Ascarid larvae in impression smear. 


\section{DISCUSSION}

In this study, liver and spleen of inspected cattle were found to be infected with a wide variety of parasites such as; Theileria spp., T. gondii and Ascarid larva. As shown in table (1) and figure (1) the total prevalence rate of Theileria spp. infection inspected carcass was (50/80) $62 \%$ in liver \& about (12/20) $60 \%$ in spleen. Similar result was observed by Usman et al. (2016) in Nigeria, who noticed that the infection rate of cattle was $60.4 \%$. However, Yahaya and Tyav (2014) found that the infection of cattle was $34.9 \%$. The protozoa infections were the most predominant parasites among cattle; the prevalence of identified protozoa was $59.3 \%$. The prevalence rate of protozoa infection differed among studies were higher in cattle farms and villages of EL-Wadi EL-Gadid, Assiut, ELFayoum, EL- Minia and Sohage Governorates which were examined 150 cattle for theileriosis. The infection rates in blood and lymph samples were $65.6 \%$ and $45.3 \%$, respectively, while PCR test showed that $58.3 \%$ were positive (Abdel-Rady et al., 2010). In Taiwan, $81.3 \%$ for cattle (Huang et al., 2014) and lower results evaluated in the different localities in Upper Egypt were; $17.5 \%$ in Assiut, $20 \%$ in Sohag and $40 \%$ in El-Wadi El-Gadid Governorates by Abdel-Rady et al., (2008). A total of 405 cattle were randomly sampled in Menofia Province, Egypt the total prevalence of Theileria sp. in infected cattle was $65(16.05 \%)$ (Nayel et al., 2012). In Pakistan, $13.62 \%$ for cattle (Rafiullah et al., 2011), in India, $10.76 \%$ in cattle (Choubisa and Jaroli 2013), and in Cheyyartaluk, 16\% (Vanisri et al., 2016). In our results, schizonts were seen in smears made from liver $62.5 \%$ and spleen $60 \%$. The presence of schizonts in liver and spleen have been recognized before by Yin et al. (2003) and Kaleibar et al. (2014) in Iran who found Koch's blue bodies (Macroschizont) on tissue sections of the bone marrow, liver, kidney, and heart.

Theileria spp. responsible for the economically important diseases of domestic and wild animals. Theileria spp. classification based on morphology, host cells in which schizogony occurs, the observation of piroplasms in the red blood cells associated with disease manifestation and host-vector specificity. The genus Theileria is distinguished by infection of leukocytes by sporozoites, maturation of schizonts into merozoites and subsequent infection of red blood cells to form piroplasms (Uilenberg, 2006). The infective stage called sporozoites during tick feeding into the feeding site. Sporozoites then infect leukocytes and multiply, larval or nymphal vector ticks ingest piroplasms and released it in tick gut, were forming a zygote, which divides into motile kinetes and infects the tick gut epithelial cells and migrates to the haemolymph and salivary glands (McKeever, 2009). Theileria epidemiology considers parasite and vector distribution mortality and morbidity of disease outbreaks, disease outbreak risk assessment, and disease control measures, socioeconomic factors, climate change, host resistance and susceptibility (Gachohi et al., 2012). Theileria had a clinical disease characterized by theilerial parasitemia, macrocytic normochromic anemia with acanthocytosis and spherocytosis, lymphoid hyperplasia (lymphocytosis, edematous lymphadenomegaly), dysproteinemia, evidence of liver disease, and a low serum antibody titer against Theileria spp. which also can affect the spleen, which developed mild anemia while parasitemic (Alvarado-Equivel et al., 2011).

As shown in table (1) and figure (1) T. gondii was detected in one liver and two spleens of cattle as following; $1 / 80(1.25 \%)$ and 2/20 (10\%) liver \& spleen respectively, as the highest rate was observed in spleen. This also agree with Mohammed and Abdullah (2013) in Sulaimani Province, who recognized tissue cysts of $T$. gondii in liver and spleen stained by Geimsa stain by about $11 \%$. Nearly similar results reported In Bangladesh $12 \%$ in spleen of cattle by Shahiduzzaman et al. (2011). Azizi et al. (2014) investigated $T$. gondii in cattle infection in Southwest of Iran by $12 \%$ from cattle spleen. A total of 30, 742 individual samples from 24 countries in Africa, the overall estimated prevalence of toxoplasmosis in cattle was $12 \%$ (8-17\%) (Tonouhewa et al., 2017). Higher results were detected from 88 cows in Egypt, seroprevalence of toxoplasmosis was $17(19.3 \%)$ by Hassanain et al. (2013). In Brazil, about $26 \%$ of $T$. gondii was detected in beef cattle by Santos et al. (2009). Lower results estimated by Inpankaew et al. (2010) in Thailand who detected $9.4 \%$ of $T$. gondii infection in cows. T. gondii prevalence in New Caledonia Cattle was $3.3 \%$ by Roqueplo et al. (2011). Gharekhani (2013) determined $2.3 \%$ of the cattle samples infected with T. gondii in Western Iran. Ahmad and Qayyum, (2014) reported in northern Punjab, Pakistan, about $T$. gondii infection was $19.75 \%$ (79/400) from cattle samples. Matsuo et al. (2014) found T. gondii in 7.3\% (31/422) of cattle in Japan. T. gondii is an intracellular protozoan parasite that can infect almost all warm-blooded animals, including humans because Toxoplasma gondii can infect a variety of intermediate hosts such as; warm-blooded animals and man. The definitive host for this parasite is feline species. Cat completes the coccidian life cycle with intestinal replication and passage of oocysts in the feces (Robert-Gangneux \& Darde, 2012 and Lu, et. al., 2015). Humans infected primarily by intake raw or undercooked meat and offals containing viable tissue cysts, or by ingesting water or food contaminated with oocysts from infected cat feces. In healthy humans, the infection with $T$. gondii is usually asymptomatic. It causes severe encephalitis and neurologic diseases, and can affect the heart, liver, inner ears, and eyes (chorioretinitis) (Meireles, 
et. al., 2015). Primary infections in pregnant women are normally asymptomatic in the mother; but the importance of estimating T.gondii infection in human has a great significance because of the risk of the infection of the fetus, immune compromised hosts and newborns (Baldursson, \& Karanis, 2011 and Ahmad, \& Qayyum, 2014).

This result showed that five percent of cattle using Giemsa stained impression smear have been infected by Ascarid larva, which was found mainly in spleen. These findings were confirmed by (Strube et al., 2013) who estimated that the larvae do not develop into the adult stage, but rather migrate throughout the somatic tissue and persist as an infectious L3 stage for extensive periods. Those arrested larvae may lead to severe inflammatory reactions and consequently to a wide range of pathological and clinical manifestations. Ascaris has enormous reproductive potential and it has been estimated that a single female may produce more than 1 million eggs per day and remain viable in the soil for at least 6 years and contaminate the environment through fertilizer (Roepstorff et al., 2011). Most Ascarid larvae are expelled from the hepato-tracheal migration animal tissue and probably human hosts and be unobservable by the naked eye which makes it hardly detected in medical and veterinary practice (Nejsum et al., 2009 and Pinelli et al., 2011). Zoonotic Ascaris infection is generally thought to be uncommon in humans in developed countries and associated with the previous residence in, or travel to, endemic areas (Maguire, 2005) or due to foodborne infection (Bendall et al., 2011). Some studies report on Ascaris in lambs with affected livers (Criscione et al., 2007) and lungs due to swine cross-infection migration (Lee et al., 2010).

\section{CONCLUSION}

The effect of parasitic diseases remains one of the most important diseases of cattle in New-Valley Governorate and it is the main cause of reduced cattle productivity. In the present study, cattle may be considered as a reservoir host for Toxoplasma human infection which represents a serious human public health problem. The present results provide baseline data for future researchers and control strategies against parasites of cattle. More farmers, veterinarian, and public awareness, education programs, and improvement of post mortem inspection legislation and procedures are recommended. Strategic deworming of animals, when conditions are favorable for larval development on the pasture using broadspectrum anthelmintic must be applied. All public health measures should be encouraged, including thorough handwashing with soap (particularly for children) and rinsing and cooking of vegetables. Future molecular biological studies are recommended to find out if the Theileria spp., Toxoplasma spp. and Ascarid larvae encountered in New-Valley cattle are pathogenic human genotypes which will represent a serious health problem for populations who comes in contact with cattle.

\section{ACKNOWLEDGMENT}

The authors gratefully thank the managers of ElKharga abattoirs for their help in the examination of the slaughtered animals and providing the samples under the study. This work was financed by the author only and wasn't carried out within any framework of the project.

\section{REFERENCES}

Abdel-Rady, A.; Ahmed, L.S.; Mohamed, A. and AlHosary, A. (2010): Using polymerase chain reaction (PCR) for diagnosis of bovine theileriosis in Upper Egypt. IJAVMS, 4(3): 67-74.

Abdel-Rady, A.; Kotb, S. and Abd Ellah, M.R. (2008): Clinical, Diagnostic And Therapeutic Studies On Theileriasis (Theileria Annulata) In Cattle In Upper Egypt. SCVMJ, XIII13 (2): 387-395.

Abd El-Razik, K.A.; El fadaly, H.A.; Barakat, A.M.A. and Abu Elnaga, S.M. (2014): Zo0notic hazards $\mathrm{T}$. gondii viable cysts in ready to eat Egyptian meat-meals. World journal of medical science. 11(4): 510-517.

Abouzeid, N.; Selim, A. and El-Hady, K. (2010): Prevalence of gastrointestinal parasites infections in sheep in the Zoo garden and Sinai district and study the efficacy of anthelmintic drugs in the treatment of these parasites. Journal of American Science, 6(11): 544-551.

Adod (2014): Arab agricultural statistics yearbook Arab Organization for Agricultural Development Khartoum, Sudan. VOL. No. (34).

Ahmad, N. and Qayyum, M. (2014): Seroprevalence and risk factors for toxoplasmosis in large ruminants in northern Punjab, Pakistan. The Journal of Infection in Developing countries, 8(8): 1022-1028.

Akanda, M.; Hasan, M.; Belal, S.; Roy A.; Ahmad, S.; Das, R. and Masud, A. (2014): A survey on prevalence of gastrointestinal parasitic infection in cattle of Sylhet division in Bangladesh. American Journal of Phytomedicine and Clinical Therapeutics, 2(7): 855-860.

Alvarado-Esquivel, C.; Torres-Berumen, J.L.; Estrada-Martínez, S.; Liesenfeld, O. and Mercado-Suarez, F.M. (2011): Toxoplasma gondii infection and liver disease: a casecontrol study in a Northern Mexican population. Parasites \& Vectors journal. 1-7. 
Azizi, H.; Shiran, B.; Boroujeni, A.B. and Jafari, M. (2014): Molecular survey of Toxoplasma gondii in sheep, cattle and meat products in Chaharmahal va Bakhtiari Province, Southwest of Iran. Iranian journal of parasitology, 9(3): 429-434.

Baldursson, S. and Karanis, P. (2011): Waterborne transmission of protozoan parasites: review of worldwide outbreaks-an update 20042010. Water Res. 45, 6603-6614. doi: 10.1016/j.watres.2011.10.013

Bendall, R.P.; Barlow, M.; Betson, M.; Stothard, J.R. and Nejsum, P. (2011): Zoonotic ascariasis. United Kingdom. Emerging Infectious Diseases 17, 1964-1966.

Choubisa, S. and Jaroli, V. (2013): Gastrointestinal parasitic infection in diverse species of domestic ruminants inhabiting tribal rural areas of southern Rajasthan, India. Journal of parasitic diseases, 37(2): 271-275.

Criscione, C.D.; Anderson, J.D.; Sudimack, D.; Peng, W.; Jha, B.; Williams-Blangero, S. and Anderson, T.J.C. (2007): Disentangling hybridization and host colonization in parasitic roundworms of humans and pigs. Proceedings of the Royal Society Biological Sciences 274, 2669-2677.

Elmonir, W.; Mousa, W. and Sultan, K. (2015): The Prevalence of Some Parasitic Zoonoses in Different Slaughtered Animal Species at Abattoir in the Mid-Delta of Egypt; with Special Reference to its Economic Implications. Alexandria Journal for Veterinary Sciences, 47(1): 97-103.

Gachohi, J.; Skilton, R.; Hansen, F.; Ngumi, P. and Kitala, P. (2012): Epidemiology of East Coast fever (Theileria parva infection) in Kenya: past, present and the future. Parasitology vector journal. 5: 194.

Gharekhani, J. (2013): Serological study of Toxoplasma gondii infection in cattle from western Iran. Sci. Parasitol, 14(3): 153-157.

Griffiths, H.J. (1978): A handbook of veterinary parasitology: domestic animals of North America University of Minnesota Press, pp 210.

Hassanain, M.A.; El-Fadaly, H.A.; Hassanain, NA.; Shaapan, R.M.; Barakat, A.M. and Abd El-Razik, K. (2013): Serological and molecular diagnosis of toxoplasmosis in human and animals. World Journal of Medical Sciences, 9(4): 243-247.

Huang, CC.; Wang, LC.; Pan, CH.; Yang, CH. and Lai, $\quad C H . \quad$ (2014): Investigation of gastrointestinal parasites of dairy cattle around Taiwan. Journal of Microbiology, Immunology Infection, 47(1): 70-74.

Inpankaew, T.; Pinyopanuwut, N.; Chimnoi, W.; Kengradomkit, C.; Sununta, C.; Zhang, G.; Nishikawa, Y.; Igarashi, I.; Xuan, X.; Jittapalapong, $S J T$. and Diseases, $E$.
(2010): Serodiagnosis of Toxoplasma gondii infection in dairy cows in Thailand, 57(1-2): 42-45.

Kaleibar, M.T.; Helan, J.A. and Fathi, E. (2014): Occurrence of congenital cerebral theileriosis in a newborn twin Holstein calves in Iran: Case report. Veterinary Research Forum, 5 (3): 237 - 241.

Khan, M.N.; Sajid, M.S.; Khan, M.K.; Iqbal, Z. and Hussain, A. (2010): Gastrointestinal helminthiasis: prevalence and associated determinants in domestic ruminants of district Toba Tek Singh, Punjab, Pakistan. Parasitology research, 107(4): 787-794.

Lawrence, RA. and Thomas, C.O. (1987): Parasites A guide to laboratory procedures and identification Press American Society of Clinical Pathologists, Chicago 99-104 vols.

Lee, A.C.; Schantz, P.M.; Kazacos, K.R.; Montgomery, S.P. and Bowman, D.D. (2010): Epidemiologic and zoonotic aspects of ascarid infections in $\operatorname{dogs}$ and cats. Trends in Parasitology 26, 155-161.

Leonard, E.G.; Kishamawe, C.; Kimario, E. and Rumisha, S.F. (2019): Mortality Patterns of Toxoplasmosis and Its Comorbidities in Tanzania: A 10-Year Retrospective Hospital-Based Survey. Front Public Health 7, 25.

Lu, N.; Liu, C.; Wang, J.; Ding, Y. and Ai, $Q$. (2015): Toxoplasmosis complicating lung cancer: a case report. Int. Med. Case Rep. J. 8, 37-40. doi: 10.2147/ IMCRJ.S76488.

Maguire, J. (2005): Intestinal roundworms. pp. 3260-3267 in Mandell, G.L., Bennett, J.E. \& Dolin, R. (Eds) Principles and practice of infectious diseases. 6th edn. Philadelphia, Elsevier.

Maslin, W.R. and Latimer, K.S.J.A.D. (2009): Atoxoplasmosis in canary fledglings: severe lymphocytic enteritis with preferential parasitism of B lymphocytes, 53(3): 473476.

Matsuo, K.; Kamai, R.; Uetsu, H.; Goto, H.; Takashima, Y. and Nagamune, K. (2014): Seroprevalence of Toxoplasma gondii infection in cattle, horses, pigs and chickens in Japan. Parasitology international, 63(4): 638-639.

McKeever, D.J. (2009): Bovine immunity - a driver for diversity in Theileria parasites? Trends Parasitology. 25: 269-276.

Meireles, L.R.; Ekman, C.C.; De Andrade, H.F.Jr. and Luna, E.J. (2015): Human toxoplasmosis outbreaks and the agent infecting form. Findings from a systematic review. Rev. Inst. Med. Trop. Sao. Paulo. 57, 369-376. doi: 10.1590/S003646652015000500001

Mohammed, A.A. and Abdullah, S.H. (2013): Diagnostic Study of Toxoplasmosis in 
Domestic Chickens in Sulaimani Province. AL-Qadisiya Journal of Vet. Med. Sci., 12 (2): 63-69.

Morrison, W.I. (2015): The etiology, pathogenesis and control of theileriosis in domestic animals. Rev. Sci. Tech. Off. Int. Epiz. 34 (2): 599-611.

Nayel, M.; El-Dakhly, K.M.; Aboulaila, M.; Elsify, A.; Hassan, H.; Ibrahim, E.; Salama, A. and Yanai, T. (2012): The use of different diagnostic tools for Babesia and Theileria parasites in cattle in Menofia, Egypt. Parasitology research, 111(3): 1019-1024.

Nejsum, P.; Thamsborg, S.M.; Petersen, H.H.; Kringel, H.; Fredholm, M. and Roepstorff, A. (2009): Population dynamics of Ascarissuum in trickle-infected pigs. Journal of Parasitology 95, 1048-1053.

Pam, V.; Ogbu, K.; Igeh, C.; Bot, C. and Vincent, G. (2013): The occurrence of gastrointestinal and haemo parasites of cattle in Jos of Plateau State, Nigeria. Journal of Animal Science Advances, 3(2): 97-102.

Phiri, A. (2006): Common conditions leading to cattle carcass and offal condemnations at 3 abattoirs in the Western Province of Zambia and their zoonotic implications to consumers. Journal of the South African Veterinary Association, 77(1): 28-32.

Pinelli, E.; Herremans, T.; Harms, M.G.; Hoek, D. and Kortbeek, L.M. (2011): Toxocara and Ascaris seropositivity among patients suspected of visceral and ocular larva migrans in the Netherlands: trends from 1998 to 2009. European Journal of Clinical Microbiology and Infectious Diseases 30, 873-879.

Radwan, I.G.H. (2008): Evaluation of Cysticercus bovis antigen for diagnosis of Cysticercus bovis in cattle. Egyptain Journal of Comparative Pathology and Clinical Pathology, 21(3): 250 - 262.

Rafiullah, T.A.; Sajid, A.; Shah, S.R.; Ahmad, S. and Shahid, M. (2011): Prevalence of gastrointestinal tract parasites in cattle of Khyber Pakhtunkhwa. ARPN Journal of Agricultural and Biological Science, 6(9): 915.

Raza, M.A.; Ayaz, M.M.; Murtaza, S.; Akhtar, M.S.; Naeem, M.; Ali, M. and Bachaya, H.A. (2013): Prevalence of GIT helminths in cattle at the vicinities of Tehsil Jatoi, Punjab, Pakistan. Science International (Lahore). 25(2): 305-309.

Robert-Gangneux, F. and Darde, M.L. (2012): Epidemiology of and diagnostic strategies for toxoplasmosis. Clin. Microbiol. Rev. 25, 264-296. doi: 10.1128/CMR.05013-11

Roepstorff, A.; Mejer, H.; Nejsum, P. and Thamsborg, S.M. (2011): Helminth parasites in pigs: new challenges in pig production and current research highlights. Veterinary Parasitology 180, 72-81.

Roqueplo, C.; Halos, L.; Cabre, O. and Davoust, B. (2011): Toxoplasma gondii in wild and domestic animals from New Caledonia. Parasite, 18(4): 345-348.

Santos, S.L.; De Souza Costa, K.; Gondim, L.Q.; Da Silva, M.S.A.; Uzêda, R.S.; Abe-Sandes, K. and Gondim, L.F.P. (2009): Investigation of Neospora caninum, Hammondia sp., and Toxoplasma gondii in tissues from slaughtered beef cattle in Bahia, Brazil. Parasitology Research, 106(2): 457-461.

Shahiduzzaman, M.; Islam, M.R.; Khatun, M.M.; Batanova, T.A.; Kitoh, K. and Takashima, $Y$. (2011): Toxoplasma gondii seroprevalence in domestic animals and humans in Mymensingh District, Bangladesh. Journal of Veterinary Medical Science, 73(10): 1375-1376.

Strube, C.; Heuer, L. and Janecek, E. (2013): Toxocara spp. infections in paratenic hosts. Vet Parasitol, 193(4): 375-89.

Tonouhewa, A.B.N.; Akpo, Y.; Sessou, P.; Adoligbe, C.; Yessinou, E.; Hounmanou, $Y$ G.; Assogba, M.N.; Youssao, I. and Farougou, S. (2017): Toxoplasma gondii infection in meat animals from Africa: Systematic review and meta-analysis of sero-epidemiological studies. J Veterinary world, 10(2): 194.

Uilenberg, G. (2006): Babesia-a historical overview. Vet. Parasitol. 138:3-10.

Usman, A.; Malann, Y. and Babeker, E. (2016): Prevalence of Gastrointestinal Parasitic Infections Among Ruminants Animals Slaughtered In Katagum Abattoir of Bauchi State, Nigeria. International Journal of Innovative Research Advanced Studies, 3(12): 167-170.

Vanisri, V.; Subramanian, N. and Muthu, M. (2016): Prevalence of gastrointestinal parasites in cattle in and around Cheyyar taluk, Thiruvannamalai district. International Journal of Information Research and Review, 3(11): 3282-3294.

Yahaya, A. and Tyav, Y.B. (2014): A Survey of Gastrointestinal Parasitic Helminths of Bovine Slaughtered in Abattoir, Wudil Local Government Area, Kano State, Nigeria. Greener Journal of Biological Sciences, 4(4): 128-134.

Yin, H.; Liu, G.; Luo, J.; Guan, G.; Ma, M.; Ahmed, J. and Bai, Q. (2003): Observation on the schizont stage of an unidentified Theileria sp. in experimentally infected sheep. Parasitol Res, 91, 34-39. 


\section{الكشف عن بعض طفيليات الكبا والطحال في مذبوحات المواشي \\ وفاء جمال اللدين محمود ، نجوى ثابت الشعراوي ، الشبياء حسانين ، عبير خضر}

E-mail: dr.nagwa2004@yahoo.com Assiut University web-site: www.aun.edu.eg

تسبب الإصابات الطفيلية في تأخير معدل النمو وتقليل إنتاج الألبان و اللحوم و الإجهاض و الوفيات مما قد يؤدي إلى خسائر اقتصـادية

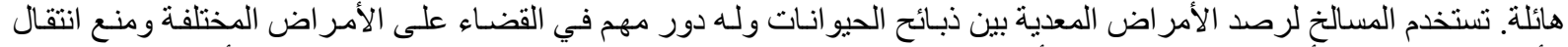

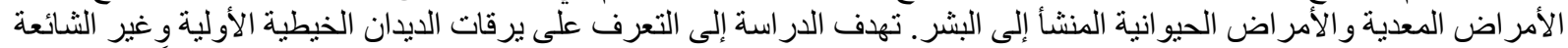

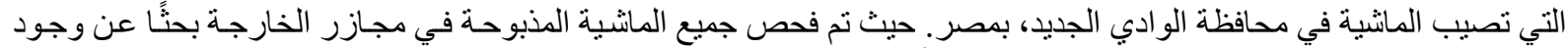

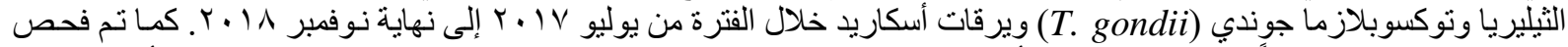

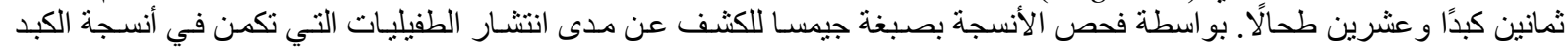

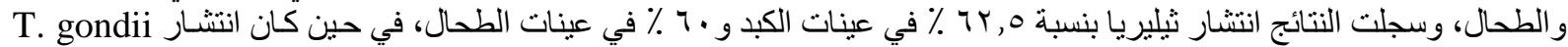

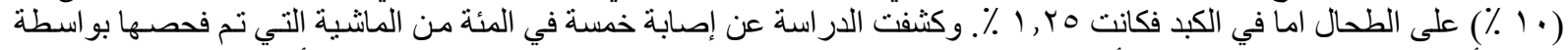

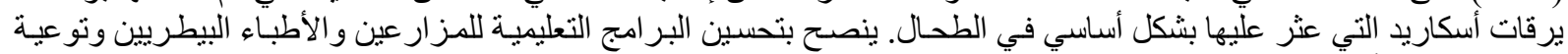

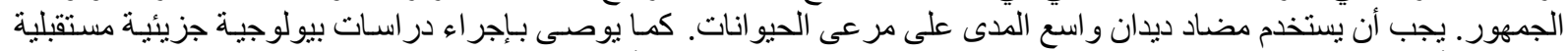

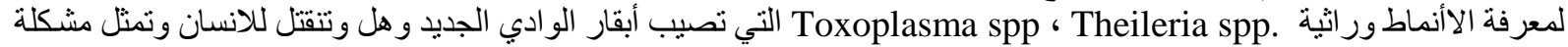
صحية خطيرة للسكان الذين ينعاملون مع المانشية. 